ISSN : 2581-1320 (Print) ISSN : 2581-2572 (Online)

Homepage: http://ejurnal.ikippgribojonegoro.ac.id/index.php/J-ABDIPAMAS

\title{
PELATIHAN PEMANFAATAN SISTEM PEMBELAJARAN DARING BAGI GURU-GURU SMA DI KECAMATAN PALAS, KABUPATEN LAMPUNG SELATAN
}

\author{
Muhammad Basri ${ }^{1}$, Yusuf Perdana ${ }^{2}$, Nur Indah Lestari ${ }^{3}$, Marzius Insani $^{4}$ \\ ${ }^{1}$ Universitas Lampung. Email: muhammad.basri@fkip.unila.ac.id \\ 2 Universitas Lampung. Email: yusuf.perdana@fkip.unila.ac.id \\ 3 Universitas Lampung. Email: nur.indahlestari@fkip.unila.ac.id \\ ${ }^{4}$ Universitas Lampung. Email: marzius.insani@fkip.unila.ac.id
}

\begin{abstract}
Along with the development of information and communication technology by utilizing the internet in all aspects of life, one of the growing utilization of the internet is in the field of education. Improving the quality of teachers, especially high school teachers, needs to be improved through various skills in material selection, teaching materials, learning media to learning models that are relevant to student needs and technological developments. However, in reality not all teachers can implement online learning, so it is necessary to conduct training on the use of learning for high school teachers, especially for high school teachers in Palas District South Lampung Regency. Presentation and demonstration methods for training carried out by training in the creation of a learning management system with google class application carried out by training participants with independent and responsible assistance. The results showed that the entire out well the increase in the knowledge of high school teachers palas subdistrict, south lampung regency towards a bold learning system with several google classroom Learning Management System platforms and google meet.
\end{abstract}

Keywords: Training, Utilization, Online Learning System

\begin{abstract}
ABSTRAK
Seiring dengan perkembangan Teknologi Informasi dan Komunikasi dengan memanfaatkan internet dalam segala aspek kehidupan, salah satu pemanfaatan internet yang sedang berkembang yakni di bidang pendidikan. Peningkatan kualitas guru-guru, khususnya guru-guru SMA perlu ditingkatkan melalui berbagai keterampilan dalam pemilihan materi, bahan ajar, media belajar hingga model pembelajaran yang relevan dengan kebutuhan siswa dan perkembangan teknologi. Akan tetapi pada kenyataannya tidak semua guru dapat mengimplementasikan pembelajaran daring, sehingga perlu dilakukan pelatihan pemanfaatan pembelajaran daring bagi guru-guru Sekolah Menengah Atas khususnya bagi guru SMA di Kecamatan Palas Kabupaten Lampung Selatan. Metode presentasi dan demonstrasi hingga pelatihan yang dilakukan dengan praktik pembuatan pengembangan learning manajemen sistem dengan aplikasi google classroom yang dilakukan oleh peserta pelatihan secara mandiri dan bertanggungjawab. Hasil pengabdian menunjukkan bahwa seluruh rangkaian kegiatan pengabdian sudah terlaksana dengan baik yang ditunjukkan dengan peningkatan pengetahuan guru-guru SMA Kecamatan Palas Kabupaten Lampung Selatan terhadap sistem pembelajaran daring dengan beberapa platform Learning Management Sistem google classroom dan google meet.
\end{abstract}

Kata Kunci: Pelatihan, Pemanfaatan, Sistem Pembelajaran Daring

\section{PENDAHULUAN}

Pendidikan memegang peranan penting dalam kemajuan suatu bangsa. Peningkatan mutu pendidikan dapat dilakukan dengan melakukan pembaharuan dibidang pendidikan terutama dalam proses pembelajaran di dalam kelas. Salah satu caranya 
adalah melalui peningkatan kualitas pembelajaran yaitu dengan pembaharuan pendekatan atau metode mengajar. Metode mengajar mengalami perkembangan seiring dengan dengan munculnya era baru yang dikenal dengan era revolusi industri 4.0, mengajar tidak dibatasi oleh ruang kelas dan waktu sehingga proses pembelajaran dapat dilakukan dimana saja dan kapan saja. Pembelajaran hakekatnya adalah usaha sadar dari seorang guru untuk membelajarkan siswanya (mengarahkan interaksi siswa dengan sumber belajar lainnya) dalam rangka mencapai tujuan yang diharapkan dengan keberhasilannya yang dilihat dari aspek produk dan proses (Emda, 2014: 68). Keefektifan pembelajaran juga dipengaruhi oleh seberapa banyak dosen mampu memanfaatkan TIK. Dewasa ini, pendekatan konvensional telah banyak ditinggalkan dan beralih ke pembelajaran berbasis komputer atau yang biasa dikenal dengan pembelajaran daring. Pada dasarnya teknologi sendiri merubah cara oranng melakukan komunikasi, berinteraksi dan beraksi dalam berbagai tugas dan aktifitasnya, tidak terkecuali proses pembelajaran (Fajrin, 2020).

Proses pembelajaran tatap muka yang biasanya dilaksanakan di dalam kelas, kini berubah menjadi pembelajaran daring atau online learning. Tentunya ini menjadi tantangan sendiri bagi pengajar. Sistem pembelajaran daring merupakan wujud implementasi dari pendidikan jarak jauh yang biasanya diaplikasikan oleh perguruan tinggi dengan tujuan meningkatkan kualitas pembelajaran.Pada kenyataan saat ini ketika bangsa Indonesia terkena dampak virus global Covid-19, yang mana beriringan dengan keluarnya kebijakan pemerintah terkait belajar dari rumah dan bekerja dari rumah maka ini menjadi tantangan tersendiri bagi guru untuk dapat mengembangkan pembelajaran daring agar guru dapat memberikan pembelajaran secara maksimal meskipun tanpa tatap muka. Pendekatan pembelajaran daring memiliki karakteristik sebagai berikut: 1). Menuntut pembelajar atau peserta didik untuk membangun dan menciptakan pengetahuan secara mandiri (constructivism), 2). Peserta didik akan berkolaborasi dengan peserta didik lain dalam membangun pengetahuannya dan memecahkan masalah secara bersama-sama (social constructivism), 3). Membentuk suatu komunitas pembelajar (community of learners) yang inklusif, 4). Memanfaatkan media laman (website) yang bisa diakses melalui internet pembelajaran berbasis komputer, kelas virtual atau digital, 5). Interaktivitas, kemandirian, aksesbilitas dan pengayaan (Ditjen GTK dalam Isman, 2016: 587). Meningkatkan ilmu pengetahuan serta keterampilan dan mengadopsi pendekatan pembaharuan dalam pembelajaran yang lebih professional bagi peserta didik adalah hal yang wajib (Subaidi, 2020).

Akan tetapi pada kenyataannya untuk mengimplementasikan pembelajaran daring ternyata guru-guru SMA khususnya guru yang berada di Kecamatan Palas Kabupaten Lampung Selatan saat ini masih mengalami beberapa kendala dan permasalahan. Adapun beberapa permasalahan yang dihadapi oleh guru diantaranya karena kurangnya pemahaman tentang berbagai aplikasi yang dapat mendukung pembelajaran daring, bahkan sebagai besar guru masih ada yang belum paham bagaimana cara menggunakan aplikasi tersebut. Universitas Lampung sebagai lembaga pendidikan yang senantiasa berkomitmen untuk ikut serta memberdayakan masyarakat Lampung dalam bidang pendidikan, ingin berkontribusi memberikan pelatihan kepada guru-guru SMA 
khususnya di Kecamatan Palas Kabupaten Lampung Selatan tentang pemanfaatan aplikasi yang dapat mendukung pembelajaran daring.

\section{METODE PELAKSANAAN}

Adapun pelaksanaan kegiatan pelatihan pemanfaatan sistem pembelajaran daring menggunakan metode presentasi dan demonstrasi hingga pelatihan yang dilakukan dengan praktik pembuatan pengembangan learning manajemen sistem dengan aplikasi google classroom yang dilakukan oleh peserta pelatihan secara mandiri dan bertanggungjawab. Pada kegiatan awal sebelum masuk materi pemanfaatan sistem pembelajaran daring yang meliputi konsep sistem pembelajaran daring yang relevan dengan kebutuhan guru dan peserta didik. Tim pengabdian memberikan pre test di awal dan post test di akhir setelah materi dipaparkan oleh narasumber sebagai evaluasi ketercapaian pelatihan pembelajaran daring. Pelatihan sendiri sebagaimana diartikan oleh Rowley dan Jackson merupakan cara untuk memperoleh pengetahuan dan keahlian sebagai hasil dari pembelajaran mengenai keahlian praktis dan pengetahuan yang berhubungan dengan kompetensi spesifik yang berguna (Rowley dan Jackson dalam Sadiyah, dkk, 2020: 103)

Setelah kegiatan pelatihan berahir, maka sistem pembelajaran daring dapat diimplementasikan oleh guru-guru SMA di Kecamatan Palas, sehingga guru dapat memanfaatkan sistem pembelajaran daring pada masa pandemi covid-19 dengan melalui salah satu platform Learning Management Sistemnya adalah google classroom. Adapun langkah-langkah dalam kegiatan pengabdian tersebut adalah sebagai berikut:

a. Memberikan pemahaman kepada guru akan pentingnya sistem pembelajaran daring. Pada tahap ini guru akan diberikan pengetahuan mengenai pentingnya pemahaman sistem pembelajaran daring, khususnya sebagai alternative pembelajaran di masa Pandemi Covid-19.

b. Memberikan pemahaman pembuatan Learning Management System Google classroom dan Google Meet. Pada tahap ini guru akan dibekali pemahaman contoh Learning Management System yang sederhana dan mudah dipahami, yakni diantaranya adalah Google Classroom dan Google Meet.

c. Memberikan pelatihan pemanfaatan fitur-fitur pada LMS Google classroom dan Google Meet. Pada tahap ini guru diberikan pelatihan langsung mengenai apa saja pemanfaatan yang dapat dilakukan ketika menggunakan Learning Management System melalui platform Google Classroom dan Google Meet yang membantu guru dalam memudahkan proses pembelajaran.

\section{HASIL DAN PEMBAHASAN}

Kegiatan pelatihan pembelajaran daring bagi guru-guru SMA di kecamatan Palas Kabupaten Lampung Selatan dilaksanakan pada tanggal 28-29 Juli 2020 bertempat di SMA Negeri 1 Palas Kecamatan Palas Kabupaten Lampung Selatan. Pelatihan pembelajaran daring bagi guru-guru SMA di Kecamatan Palas diikuti oleh 22 orang guru yang terdiri dari beberapa sekolah negeri dan sekolah swasta yang ada di Kecamatan Palas Kabupaten Lampung Selatan. Tujuan dari kegiatan ini adalah untuk meningkatkan 
motivasi guru akan menerapkan sistem pembelajaran daring yang baik dan benar, memberikan pemahaman kepada guru-guru SMA Palas tentang berbagai macam Learning Management Sistem yang salah satunya adalah google classroom dan mengetahui macammacam fitur dalam google classroom.

Pada kegiatan pengabdian ini guru-guru di SMA Palas didorong untuk memahami berbagai materi yang disajikan narasumber mengenai sistem pembelajaran daring, fiturfitu yang ada dalam LMS yang wajib dikuasai hingga mampu menerapkan LMS yang salah satu contohnya adalah google classroom dengan maksimal. Rangkaian kegiatan diantaranya adalah sambutan yang dalam hal ini dilakukan oleh kepala sekolah SMAN 1 palas, yakni bapak Sudirman, S.Pd., M.Pd, selanjutnya dibuka oleh ketua anggota pengabdian bapak Muhammad Basri, S.Pd., M.Pd beserta materinya yakni mengenai urgensi pembelajaran daring pada masa Pandemi Covid-19, materi selanjutnya dipaparkan oleh bapak Yusuf Perdana, S.Pd., M.Pd dengan membawakan materi sistem pembelajaran daring dengan konsep-konsepnya, yang terlebih dahulu diawali dengan pre test, pelatihan mengenai fitur-fitur dalam google classroom secara lengkap dipandu langsung dipandu oleh Ibu Nur Indah Lestari, S.Pd., M.Pd dan berakhir dengan pelatihan yang dibawakan bapak Marzius Insani, S.Pd., M.Pd dengan materi pemanfaatan google meet sebagai pembelajaran daring dan menutup materi sistem pembelajaran daring dengan menggunakan post test. Rangkaian kegiatan dapat dilihat melalui gambar sebagai berikut:

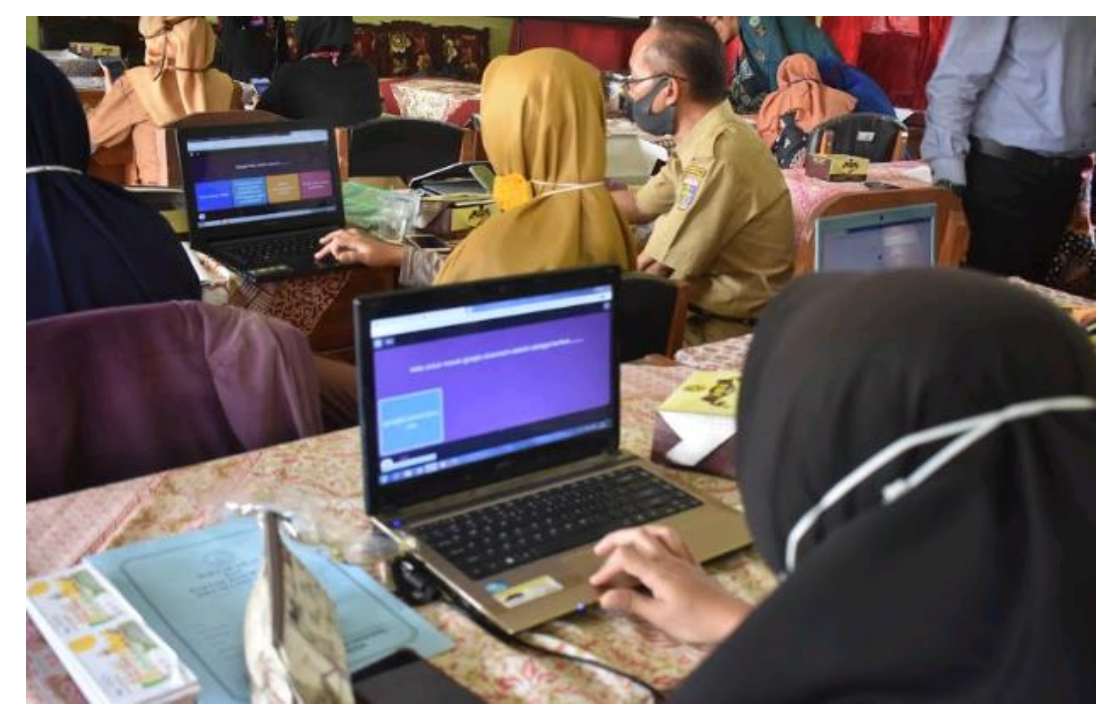

Gambar 1. Kegiatan Peserta Saat Mengikuti Post Tes

Pada sesi akhir kegiatan pelatihan pemanfaatan sistem pembelajaran daring dilakukan wawancara langsung terhadap beberapa guru-guru SMA Palas sebagai peserta pelatihan untuk mengetahui keterlaksanaan kegiatan ini. Berdasarkan hasil wawancara yang telah dilakukan oleh tim pengabdian pembelajaran daring didapatkan hasil secara mayoritas peserta yaitu guru-guru merasa tertarik dengan kegiatan yang telah dilakukan serta mengusulkan agar diadakan kegiatan sejenis namun dengan materi yang dapat mendukung pembelajaran daring yang efektif dan efisien sehingga tujuan pembelajaran dapat tercapai. 
Berdasarkan hasil evaluasi yang telah dilakukan dapat diketahui bahwa sebagian besar peserta merasakan dampak positif dan kebermanfaatan dari kegiatan yang telah dilakukan tim pengabdian pemanfaatan sistem pembelajaran daring. Pengetahuan peserta untuk mengembangkan sistem pembelajaran berbasis dalam jaringan menjadi meningkat. Skor rata-rata prosentase hasil post test peserta dari segi pengetahuan meningkat $32,17 \%$. dari hasil pre test yang dilakukan pada awal sesi kegiatan. Secara umum dalam pada proses kegiatan inti pelatihan peserta pelatihan sangat aktif menanggapi setiap stimulus yang diberikan oleh narasumber baik melalui pertanyaan yang disampaikan secara langsung pada sesi materi maupun pertanyaan yang disampaikan secara langsung pada sesi tanya jawab.

\section{SIMPULAN}

Kegiatan pengabdian pelatihan pemanfaatan sistem pembelajaran daring bagi guru-guru SMA di Kecamatan Palas Kabupaten Lampung Selatan dapat diperoleh simpulan sebagai berikut: 1) Nilai rata-rata test adalah 62,8 dan rata-rata hasil post test adalah 83,6. Prosentase peningakatan sebesar 32,17\%, dengan adanya peningkatan prosentase tersebut menunjukan bahwa pelatihan pemanfaatan sistem pembelajaran daring bagi guru SMA di Kecamatan Palas Kabupaten Lampung Selatan yang diberikan oleh tim pengabdian dapat memberikan manfaat bagi peningkatan pengetahuan dan kemampuan guru dalam menggunakan berbagai aplikasi untuk mendukung pembelajaran daring. 2) Guru-guru SMA di Kecamatan Palas Kabupaten Lampung Selatan menjadi paham dan memiliki kemampuan dalam membuat learning management system (LMS) di aplikasi google classrrom dan google meet yang sesuai dan relevan dengan kebutuhan siswa saat pembelajaran daring.

\section{DAFTAR RUJUKAN}

Emda, A. (2014). Penerapan Model Pembelajaran Kooperatif Tipe TPS Di SMA Negeri 12 Banda Aceh. lantanida Journal, 1(1), 68.

Fajrin, C. E. (2020). Pelatihan pemanfaatan cloud storage dan weblog bagi sman 11 pulau buluh. J-ABDIPAMAS (Jurnal Pengabdian Kepada Masyarakat), 4(1), 109.

Isman, M. (2016). Pembelajaran Moda Dalam Jaringan (Moda Daring). The Progressive and Fun education Seminar. The Progressive and Fun Education Seminar. Sumatera Utara: Fakultas Keguruan dan Ilmu Pendidikan Universitas Muhammadiyah Sumatera Utara.

Khalimatus Sadiyah, M. F. (2020). Pendampingan penyusunan perangkat pembelajaran kurikulum 2013 bagi guru madrasah aliyah. J-ABDIPAMAS Uurnal Pengabdian Kepada Masyarakat), 4(103), 103.

Subaidi, M. P. (2020). Pelatihan penulisan buku ajar bagi guru di MA Safinatul Huda Sowan Kidul Kedung Jepara. J-ABDIPAMAS (Jurnal Pengabdian Kepada Masyarakat), 4(1), 94. 
58 J-Abdipamas, Vol. 4, No. 2 Oktober, 2020 